\title{
The Importance of the Presence of a 5'-Ribonucleotide and the Contribution of the T1R1 + T1R3 Heterodimer and an Additional Low-Affinity Receptor in the Taste Detection of L-Glutamate as Assessed Psychophysically
}

\author{
Kimberly R. Smith and Alan C. Spector \\ Department of Psychology and Program in Neuroscience, Florida State University, Tallahassee, Florida 32306-4301
}

The molecular receptors underlying the purported "umami" taste quality commonly associated with L-glutamate have been controversial. Evidence supports the involvement of the T1R1 + T1R3 heterodimer, a GPCR broadly tuned to L-amino acids, but variants of two mGluRs expressed in taste buds have also been implicated. Using a rigorous psychophysical taste-testing paradigm, we demonstrated impaired, if not eliminated, detection of MSG in WT and T1R1, T1R2, T1R3, and T1R2 + T1R3 K0 mice when the contribution of sodium was minimized by the epithelial sodium channel blocker amiloride. When inosine $5^{\prime}$-monophosphate (IMP), a ribonucleotide that potentiates the L-glutamate signal through the T1R1 + T1R3 heterodimer, was added, the WT and T1R2 K0 mice were able to detect the compound stimulus across all MSG ( + amiloride) concentrations due, in part, to the taste of IMP. In contrast, mice lacking T1R1 or T1R3 could not detect IMP alone, yet some were able to detect MSG + amiloride + IMP, but only at the higher MSG concentrations. Interestingly, the sensitivity of T1R1 KO mice to another L-amino acid, lysine, was unimpaired, suggesting that some L-amino acids can be detected through T1R1 + T1R3-independent receptors without sensitivity loss. Given that IMP is not thought to affect mGluRs, behavioral detection of L-glutamate appears to require the contribution of the T1R1 + T1R3 receptor. However, the partial competence observed in some T1R1 and T1R3 K0 mice when MSG + amiloride + IMP was tested suggests that a T1R1 or T1R3 homodimer or an unidentified protein, perhaps in conjunction with T1R1 or T1R3, can serve as a low-affinity taste receptor for L-glutamate in the presence of IMP.

Key words: amino acids; gustatory; psychophysics; taste receptors; taste sensitivity

\section{Introduction}

The role of L-glutamate as a signaling molecule in the nervous system is well known, but this L-amino acid also stimulates taste receptors in the oral cavity where it is thought to serve as an indicator of protein-rich foods and promote feeding. Monosodium glutamate (MSG), the salt form of L-glutamate, is the prototypical stimulus for the purported fifth basic taste "umami" described as a "savory" quality. In rodents, MSG has also been

\footnotetext{
Received Jan. 29, 2014; revised Aug. 12, 2014; accepted Aug. 19, 2014.

Author contributions: K.R.S. and A.C.S. designed research; K.R.S. performed research; K.R.S. and A.C.S. analyzed data; K.R.S. and A.C.S. wrote the paper.

This work was supported by National Institutes of Health R01-DC004574 to A.C.S. and National Science Foundation GRF to K.R.S. We thank Dr. Charles Zuker for generously providing the mouse breeding pairs; and Ginger Blonde, Tom Shakar, Katie Chandler, Andrea Comisky, Ally Davis, John Paul Kolcun, Shelbi Nelson, and Kelly Palmer for help with data collection. Portions of this work were conducted in partial fulfillment of the requirements for a Doctor of Philosophy degree and were presented at the International Symposium on Olfaction and Taste in Stockholm, Sweden in June 2012, the Annual Meeting of the Society for the Study of Ingestive Behavior in New Orleans in July 2013, and the Annual Meeting of the Association for Chemoreception Sciences in Huntington Beach, California in April 2013

The authors declare no competing financial interests.

Correspondence should be addressed to Dr. Alan C. Spector, Department of Psychology and Program in Neuroscience, Florida State University, 1107 W Call Street, Tallahassee, FL 32306-4301. E-mail: spector@psy.fsu.edu.

DOI:10.1523/JNEUROSCI.0417-14.2014

Copyright $\odot 2014$ the authors $\quad 0270-6474 / 14 / 3413234-12 \$ 15.00 / 0$
}

attributed sweet and salty taste qualities as determined by conditioned taste aversion studies (Ninomiya and Funakoshi, 1989; Heyer et al., 2003).

Two classes of GPCRs have been posited as the primary taste sensors for L-glutamate: variants of the mGluR subtypes 1 and 4 (e.g., Chaudhari et al., 1996, 2000; San Gabriel et al., 2009) and the T1R1 + T1R3 heterodimer (Li et al., 2002; Nelson et al., 2002; Damak et al., 2003; Zhao et al., 2003). The mGluRs are primarily expressed in the taste buds of the circumvallate and foliate papillae in the back of the tongue (Chaudhari et al., 1996, 2000; San Gabriel et al., 2009), whereas T1R1 + T1R3 is predominantly localized in the taste buds of the fungiform papillae in the anterior tongue (Nelson et al., 2001; e.g., Kitagawa et al., 2007). The chorda tympani nerve, innervating the anterior tongue, shows a robust amplification of the L-glutamate response when $5^{\prime}$ ribonucleotides, such as inosine monophosphate (IMP), are present (Damak et al., 2003; Zhao et al., 2003; e.g., Kusuhara et al., 2013). This signal synergism is the hallmark of "umami" taste and is not observed in T1R1 or T1R3 KO mice (Zhao et al., 2003; Yasuo et al., 2008; Kusuhara et al., 2013). In contrast, the glossopharyngeal nerve innervating taste buds in the posterior tongue, where mGluRs appear to be preferentially expressed, shows responses to IMP and MSG when orally applied separately but no 
signal synergism when MSG and IMP are presented in combination (Ninomiya et al., 1991, 1992; Sako et al., 2000; Damak et al., 2003; Inoue et al., 2004; Kitagawa et al., 2007; Yasuo et al., 2008; Kusuhara et al., 2013). Thus, the IMP-induced signal amplification of L-glutamate is thought to be mediated by T1R1 + T1R3 and not the mGluRs (Li et al., 2002; Nelson et al., 2002; Zhao et al., 2003; Xu et al., 2004).

Electrophysiological approaches incorporating mGluR agonists and antagonists and/or gene $\mathrm{KO}$ preparations can determine whether L-glutamate and IMP signals are reaching the brain and provide some insight into receptor mechanisms. However, these approaches do not inherently reveal how those signals are used by central gustatory circuits. This critical additional step in discerning the functional significance of such peripheral signals requires a behavioral approach.

Here we used a psychophysical taste-testing procedure adapted for mice to functionally assess the consequences of the deletion of the T1R1 or T1R3 receptor subunit on the taste detection of small samples (only a few licks) of MSG (mixed with and without the epithelial sodium channel [ENaC] blocker amiloride), IMP (mixed with amiloride), and MSG + IMP (mixed with amiloride). Because L-glutamate appears to additionally possess a sucrose-like quality in rodents, mice lacking T1R2 were also tested. Finally, T1R1 KO and WT mice were tested for their ability to detect the "non-umami" amino acid L-lysine.

\section{Materials and Methods}

\section{Experiment 1}

Subjects. The original male and female breeding pairs were homozygous null for the T1R2 or T1R3 gene (derived from 129X1/SvJ (129) mice and backcrossed with C57BL/6J (B6) mice for at least three generations) and were provided by Dr. Charles Zuker (Columbia University, New York). These mice were crossed with WT B6 mice (The Jackson Laboratory) to produce T1R2 or T1R3 heterozygous mice. The T1R2 heterozygous mice were paired to produce T1R2 WT and homozygous null offspring, and the T1R3 heterozygous mice were paired to produce T1R3 WT and homozygous null offspring. From these litters, male WT and KO littermates were selected for subject pairs in the experiment ( $N=6$ /genotype). Not all of these subjects were retained in the experiment as a result of death or failure to meet the established criterion (discussed below), but the littermates were retained. Before and at the conclusion of the experiment, ear samples and tail samples, respectively, were shipped to Transnetyx for genotype confirmation of the T1R2 or T1R3 genotype status by real-time PCR.

All T1R2 and T1R3 animals were adults at the start of the experiment with a body weight range of 30.3-51.6 g and 24.4-45.3 g, respectively. The mice were individually housed in plastic tub cages and maintained in a temperature- and humidity-controlled room on a $12 \mathrm{~h}: 12 \mathrm{~h}$ light:dark cycle. Mice had their water bottles removed on Sunday, and training and testing were conducted on Monday through Friday. Animals were no more than $23.5 \mathrm{~h}$ water-deprived throughout the experiment and were given ad libitum access to water (deionized, reverse osmosis) at the conclusion of the Friday session until the following Sunday when the waterrestriction schedule was reintroduced. When in their home cage, mice had constant access to laboratory chow (LabDiet, 5001 Rodent Diet). Body mass and body condition scores were recorded each morning before testing to monitor the health of the animals. When an animal fell $<85 \%$ of its most recent predeprived weight or dropped in body condition scores, 1 or $2 \mathrm{ml}$ of supplemental water was given at least $1 \mathrm{~h}$ after the test session. All procedures were approved by the Florida State University Animal Care and Use Committee.

Stimuli. All stimuli were reagent grade and prepared in deionized, reverse-osmosis water. The chemicals for discrimination training and detection testing were presented as follows: sodium chloride $(\mathrm{NaCl}$; Fisher Scientific), L-glutamic acid monosodium salt hydrate (MSG; Sigma), MSG mixed with $100 \mu \mathrm{m}$ amiloride hydrochloride (Sigma),
MSG mixed with $100 \mu \mathrm{M}$ amiloride and $2.5 \mathrm{~mm}$ inosine $5^{\prime}$ monophosphate disodium salt (IMP; Sigma), and $2.5 \mathrm{~mm}$ IMP mixed with $100 \mu \mathrm{M}$ amiloride.

Apparatus. Experiments were conducted in the gustometer $(81.3 \mathrm{~cm} \times$ $33.9 \mathrm{~cm} \times 35.6 \mathrm{~cm}$, inside dimensions), a computer-controlled apparatus that measured licking and delivered precise volumes of specific taste stimuli. A testing cage $(30.2 \mathrm{~cm} \times 17.9 \mathrm{~cm} \times 21.2 \mathrm{~cm})$ having three Plexiglas sides and a front stainless steel panel with left, right, and centrally located slots $(4.5 \mathrm{~mm} \times 20 \mathrm{~mm}) 4 \mathrm{~cm}$ from the cage floor was housed within a sound-attenuating chamber (Treesukosol and Spector, 2012). The animal obtained access to the taste sample delivered onto the center sample ball, which was free to rotate on its horizontal axis. The center sample ball was attached to a mechanical arm, which extended the sample ball in front of the central slot for initiation of a trial. Two licks within $250 \mathrm{~ms}$ were required of the mouse before stimulus delivery to ensure that the animal was actively engaged in the task. Following these 2 licks, a $\sim 10 \mu \mathrm{l}$ preload was delivered to coat the sample ball. In the experiments here, the mouse could take up to 5 licks within $5 \mathrm{~s}$ of the first lick, with each lick delivering $\sim 1 \mu \mathrm{l}$ of the tastant to the ball. Following sampling, the center ball was retracted from the animal's reach, and the animal had to respond to the stimulus within $15 \mathrm{~s}$ by licking a left or right reinforcement ball, dependent upon the stimulus delivered, to receive the water reinforcer upon a correct response. The water reinforcer was available from the respective reinforcement ball for $5 \mathrm{~s}$ or up to 15 licks $(\sim 1 \mu \mathrm{l}$ of water per lick), whichever came first. Incorrect responses resulted in a $30 \mathrm{~s}$ time-out, which delayed the beginning of a new trial and therefore access to a water reinforcer. During the intertrial interval $(\sim 6$ s), the sample ball was retracted into a basin where it was washed and dried in preparation for the next stimulus presentation. The test stimuli were separately contained in $60 \mathrm{ml}$ syringe reservoirs that connected to polytetrafluoroethylene (Teflon) tubing $(0.13 \mathrm{~cm}$ inner diameter $\times 0.19$ $\mathrm{cm}$ outer diameter), which fed into a turret that rotated and positioned tubes connected to different reservoirs for the next stimulus delivery as determined by the computer. Licks were monitored via load cells attached to the sample and reinforcement balls; thus, no electrical current was passed through the animals.

Procedure. Water-restricted subjects were trained to lick from the left and right reinforcement balls and the center sample ball. Half of the mice were trained to respond via licking the right reinforcement ball when water was delivered onto the sample ball and to respond via licking the left reinforcement ball when $0.6 \mathrm{M} \mathrm{NaCl}$ was delivered $(\mathrm{NaCl}$ was selected as the training stimulus for its T1R-independent transduction mechanisms). The contingencies were reversed for the other half of the mice (if $\mathrm{NaCl}$, then respond right; if water, then respond left). Correct responses were reinforced with delivery of up to $\sim 15 \mu$ l of water (i.e., 15 licks) directly from the reinforcement balls. In experiments in which $100 \mu \mathrm{M}$ amiloride served as the solvent for the test stimulus, $100 \mu \mathrm{M}$ amiloride was used as the reinforcer instead of water. Incorrect responses were punished with a $30 \mathrm{~s}$ time-out. Once the animals were sufficiently trained to discriminate water from $0.6 \mathrm{M} \mathrm{NaCl}$, as indicated by $\geq 80 \%$ performance, the test phase was initiated. The first test concentration presented was $0.6 \mathrm{M} \mathrm{NaCl}$ followed by $0.4 \mathrm{M}$ which was then subsequently halved (i.e., $0.2 \mathrm{M}, 0.1 \mathrm{M}, 0.05 \mathrm{M}$, etc.) on each consecutive test day. Only one concentration was presented per day. The probability of receiving a taste stimulus versus water was $p=0.5$. Test concentration days were flanked by days on which standard concentrations, those that elicited $\geq 80 \%$ accuracy (customized for each mouse), were presented. A test concentration was presented again to an animal at the completion of the concentration series if the performance of the mouse was not $\geq 80 \%$ on the preceding standard concentration session of that test concentration. At the completion of testing for the concentration series of a given compound, $0.6 \mathrm{M} \mathrm{NaCl}$ was reintroduced for at least five sessions to help maintain and assess stimulus control of behavior. A water control test, in which all stimulus tubes were filled with water and half arbitrarily labeled "tastant" while the other half labeled "water," was conducted at the end of the experiment to ensure that responses were dependent on the chemical nature of the stimulus and not on other cues associated with stimulus delivery. The training and testing schedule is outlined in Table 1. On rare occasion, there were technical difficulties with the gustometer 
Table 1. Training and testing schedule for stimulus detection

\begin{tabular}{|c|c|c|c|c|}
\hline Group & Phase & Parameters & Stimulus & Days $^{a}$ \\
\hline All & Response ball training (center, left, right; $2 \times$ ) & $25 \mathrm{~m}$ per response ball & Water & 6 \\
\hline All & Side training (left, right; $3 \times$ ) & 0 s time-out; 180 s limited hold ${ }^{b}$ & Water or $0.6 \mathrm{~m} \mathrm{NaCl}$ & 6 \\
\hline All & Alternation- $4^{c}$ & 10 s time-out; 15 s limited hold & Water versus $0.6 \mathrm{~m} \mathrm{NaCl}$ & 1 \\
\hline All & Alternation-2 & 20 s time-out; 15 s limited hold & Water versus $0.6 \mathrm{~m} \mathrm{NaCl}$ & 1 \\
\hline All & Alternation-1 & 30 s time-out; 15 s limited hold & Water versus $0.6 \mathrm{M} \mathrm{NaCl}$ & 1 \\
\hline All & Discrimination training & 30 s time-out; 15 s limited hold & Water versus $0.6 \mathrm{~m} \mathrm{NaCl}$ & $32-72^{d}$ \\
\hline All & Detection & 30 s time-out; 15 s limited hold & Water versus $0.6-0.00078 \mathrm{~m} \mathrm{NaCl}$ & $33-43$ \\
\hline All & Discrimination training & 30 s time-out; 15 s limited hold & Water versus $0.2 \mathrm{~m} \mathrm{MSG}$ & $13-28$ \\
\hline All & Detection & 30 s time-out; 15 s limited hold & Water versus $0.2-0.00078 \mathrm{~m} \mathrm{MSG}^{e}$ & $26-42$ \\
\hline All & Stimulus control & 30 s time-out; 15 s limited hold & Water versus $0.6 \mathrm{~m} \mathrm{NaCl}$ & $6-17$ \\
\hline T1R2, T1R3 & Discrimination training & 30 s time-out; 15 s limited hold & $100 \mu \mathrm{m}$ amiloride versus $0.2 \mathrm{~m} \mathrm{MSG}+100 \mu \mathrm{m}$ amiloride & 2 \\
\hline T1R2, T1R3 & Discrimination training & 30 s time-out; 15 s limited hold & $100 \mu \mathrm{m}$ amiloride versus $0.6 \mathrm{M} \mathrm{MSG}+100 \mu \mathrm{m}$ amiloride & 17 \\
\hline T1R2, T1R3 & Stimulus control & 30 s time-out; 15 s limited hold & Water versus $0.6 \mathrm{~m} \mathrm{NaCl}$ & $15-20$ \\
\hline All & Discrimination training & 30 s time-out; 15 s limited hold & $100 \mu \mathrm{m}$ amiloride versus $0.6 \mathrm{~m}$ MSG $+100 \mu \mathrm{m}$ amiloride $+2.5 \mathrm{~mm}$ IMP & $49-69$ \\
\hline All & Detection & 30 s time-out; 15 s limited hold & Water versus $0.6-0.003125 \mathrm{~m} \mathrm{MSG}+100 \mu \mathrm{m}$ amiloride $+2.5 \mathrm{~mm} \mathrm{IMP}$ & $24-26$ \\
\hline All & Discrimination training & 30 s time-out; 15 s limited hold & $100 \mu \mathrm{m}$ amiloride versus $2.5 \mathrm{~mm}$ IMP $+100 \mu \mathrm{m}$ amiloride & 2 \\
\hline All & Stimulus control & 30 s time-out; 15 s limited hold & Water versus $0.6 \mathrm{~m} \mathrm{NaCl}$ & $15-21$ \\
\hline T1R1 & Discrimination training & 30 s time-out; 15 s limited hold & Water versus $0.6 \mathrm{~m} \mathrm{~L}$-lysine & $13-17$ \\
\hline T1R1 & Detection & 30 s time-out; 15 s limited hold & Water versus $0.6-0.003125 \mathrm{~m} \mathrm{~L}$-lysine & 30 \\
\hline T1R1 & Stimulus control & 30 s time-out; 15 s limited hold & Water versus $0.6 \mathrm{~m} \mathrm{NaCl}$ & 5 \\
\hline T1R1 & Discrimination training & 30 s time-out; 15 s limited hold & $100 \mu \mathrm{m}$ amiloride versus $0.6 \mathrm{~m}$ MSG $+100 \mu \mathrm{m}$ amiloride & $20-22$ \\
\hline T1R1 & Stimulus control & 30 s time-out; 15 s limited hold & Water versus $0.6 \mathrm{~m} \mathrm{NaCl}$ & 13 \\
\hline All & Water control test & 30 s time-out; 15 s limited hold & Water & $1-2$ \\
\hline
\end{tabular}

${ }^{a}$ Number of sessions varied between experiments and phases because of variability across all mice within each experiment reaching the established criteria (see Procedure). Following Alternation-1 Training, all further session totals include only stimulus discrimination sessions, not side training sessions.

${ }^{b}$ Time-out is the duration following an incorrect response in which onset of the subsequent trial was delayed and no water was delivered from the reinforcement balls. Limited hold is time allotted for the animal to make a response after licking the stimulus from the sample ball.

Number of correct responses required before proceeding to the alternate stimulus.

${ }^{d}$ Accounts for all $\mathrm{NaCl}$ versus water discrimination days, including previous testing experience in the T1R2 + T1R3 group (see Stimuli and Procedure).

${ }^{e} \mathrm{~T} 1 \mathrm{R} 2, \mathrm{~T} 1 \mathrm{R} 3$, and T1R2 + T1R3 groups were only tested as low as $0.00156 \mathrm{M} \mathrm{MSG}$.

that required an animal to be retested on the same day or data from trials associated with a particular stimulus reservoir be discarded for that session.

Data analysis. Only trials with a response were analyzed. A one-tailed binomial distribution test was conducted for the data from the last $\mathrm{NaCl}$ training session to determine whether the animals performed above chance. One T1R3 KO mouse died during training. One T1R2 KO mouse and one T1R3 WT mouse failed to perform above chance on the last $\mathrm{NaCl}$ testing session and therefore were eliminated from the experiment. Therefore, the sample size for each group was as follows: T1R2 WT $(N=$ $6)$, T1R2 KO $(N=5)$, T1R3 WT $(N=5)$, and T1R3 KO $(N=5)$. The animals that performed above chance $(50 \%)$ on the last training session were included in a two-way ANOVA (concentration $\times$ genotype) of the overall percentage correct scores for a given test stimulus. This was followed by one-way ANOVAs and Bonferroni-corrected $t$ tests when appropriate. Of these mice, those that scored $\geq 80 \%$ on the highest test concentration were included in the threshold analysis. For the threshold analysis, psychometric functions were fit to the data for each animal and each stimulus with the following 3-parameter logistic equation:

$$
f(x)=\frac{a-50}{\left(1+10^{\left(\log _{10}(X)-c\right) b}\right)}+50
$$

where $a$ is asymptotic performance, $b$ is the slope of the curve, $c$ is the $\mathrm{EC}_{50}$ or the $\log _{10}$ stimulus concentration at the midpoint between asymptotic and chance performance, and $x$ is the stimulus concentration presented. We operationally defined the detection threshold as the $\mathrm{EC}_{50}$ value. Two-sample $t$ tests were performed on the $a, b$, and $c$ values derived from the curve fits for the animals to assess the effect of genotype. These analyses were repeated for all test stimuli. However, if an animal performed above chance for $\mathrm{NaCl}$ but did not do so on the last day of training for another stimulus, the animal was excluded from data analysis on that tastant but remained in the experiment. Last, no concentration series was presented for MSG with amiloride and a one-tailed binomial distribution test was performed on the overall percent correct score on the last training session to determine whether each mouse performed significantly above chance. A two-way ANOVA and one-tailed binomial distribution test were conducted on the overall percent correct scores to assess performance on the discrimination of $2.5 \mathrm{~mm}$ IMP with amiloride versus amiloride alone. A similar one-tailed binomial test was performed on the overall percent correct scores on the water control test.

\section{Experiment 2}

Subjects. The original male and female breeding pairs were homozygous null for the T1R2 or T1R3 gene (derived from 129 mice and backcrossed with B6 mice for at least three generations) and were provided by Dr. Charles Zuker (Columbia University). These mice were crossed with WT B6 mice (The Jackson Laboratory) to produce T1R2 or T1R3 heterozygous mice. These heterozygous mice were crossed to produce T1R2 homozygous null offspring or T1R3 homozygous null offspring. These T1R2 homozygous null mice were crossed with T1R3 homozygous null mice to produce T1R2 + T1R3 heterozygous mice, which were then crossed to eventually generate T1R $2+\mathrm{T} 1 \mathrm{R} 3$ homozygous null mice $(N=10 ; 5$ male, 5 female) for this experiment. T1R2 WT and T1R3 WT mice served as controls in this experiment $(N=10 ; 5$ male, 5 female). All T1R2 + T1R3 animals were adults at the start of the experiment with a body weight range of 20.8-39.1 g. The mice were maintained in the same conditions as in Experiment 1. Not all of these subjects were tested throughout the entirety of the experiment as a result of death. Genotypes were confirmed as in Experiment 1.

Stimuli and procedure. Mice were trained in gustometers identical to those in Experiment 1. Training and testing protocols were similar to Experiment 1 with minor adjustments to the test stimuli presented ( $\mathrm{Ta}$ ble 1). The testing of $\mathrm{NaCl}$ in these mice was interrupted on two occasions because of unforeseen medical issues with personnel (these days are included as Discrimination Training in Table 1). We reinstated the training phase and then conducted a continuous testing phase (which was used in the analysis). Because we were unable to train the individual T1R2 mice and T1R3 mice in Experiment 1 to proficiently discriminate $0.6 \mathrm{M}$ MSG prepared with $100 \mu \mathrm{M}$ amiloride from $100 \mu \mathrm{M}$ amiloride alone, we 
Table 2. ANOVA values comparing WT and K0 mice performance within the T1R1, T1R2, T1R3, and T1R2 + T1R3 groups that performed above chance (50\%) on the highest test concentration presented of each test stimulus

\begin{tabular}{|c|c|c|c|}
\hline Group & Genotype & Concentration & Genotype $\times$ concentration \\
\hline \multicolumn{4}{|l|}{$\mathrm{NaCl}$} \\
\hline T1R1 & $F_{(1,15)}=0.500, p=0.490$ & $F_{(10,150)}=79.552, p<0.001^{*}$ & $F_{(10,150)}=0.556, p=0.847$ \\
\hline T1R2 & $F_{(1,9)}=0.874, p=0.374$ & $F_{(10,90)}=72.379, p<0.001^{*}$ & $F_{(10,90)}=1.432, p=0.179$ \\
\hline $\mathrm{T} 1 \mathrm{R} 2+\mathrm{T} 1 \mathrm{R} 3$ & $F_{(1,14)}=0.770, p=0.395$ & $F_{(10,140)}=85.761, p<0.001^{*}$ & $F_{(10,140)}=1.046, p=0.408$ \\
\hline \multicolumn{4}{|c|}{ 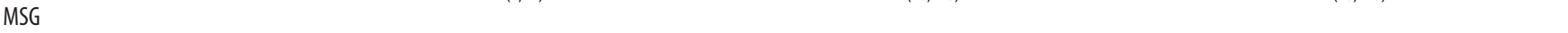 } \\
\hline T1R1 & $F_{(1,15)}=0.226, p=0.642$ & $F_{(8,120)}=145.303, p<0.001^{*}$ & $F_{(8,120)}=0.436, p=0.897$ \\
\hline $\mathrm{T} 1 \mathrm{R} 2+\mathrm{T} 1 \mathrm{R} 3$ & $F_{(1,13)}^{(1,0)}=1.024, p=0.330$ & $F_{(7,91)}=78.211, p<0.001^{*}$ & $F_{(7,91)}=1.473, p=0.187$ \\
\hline \multicolumn{4}{|c|}{ MSG $+100 \mu \mathrm{M}$ amiloride $+2.5 \mathrm{~mm} \mathrm{IMP}$} \\
\hline T1R1 & $F_{(1,11)}=61.328, p<0.001^{*}$ & $F_{(8,88)}=7.199, p<0.001^{*}$ & $F_{(8,88)}=6.347, p<0.001^{*}$ \\
\hline T1R2 & $F_{(1,9)}=6.310, p=0.033^{*}$ & $F_{(8,72)}=3.919, p<0.001^{*}$ & $F_{(8,72)}^{(0,8)}=1.673, p=0.120$ \\
\hline T1R3 & $F_{(1,6)}=57.047, p<0.001^{*}$ & $F_{(8,48)}=5.417, p<0.001^{*}$ & $F_{(8,48)}=2.358, p=0.032^{*}$ \\
\hline $\mathrm{T} 1 \mathrm{R} 2+\mathrm{T} 1 \mathrm{R} 3$ & $F_{(1,9)}=190.4, p<0.001^{*}$ & $F_{(8,72)}=5.515, p<0.001^{*}$ & $F_{(8,72)}=4.649, p<0.001^{*}$ \\
\hline
\end{tabular}

*Significant effects.

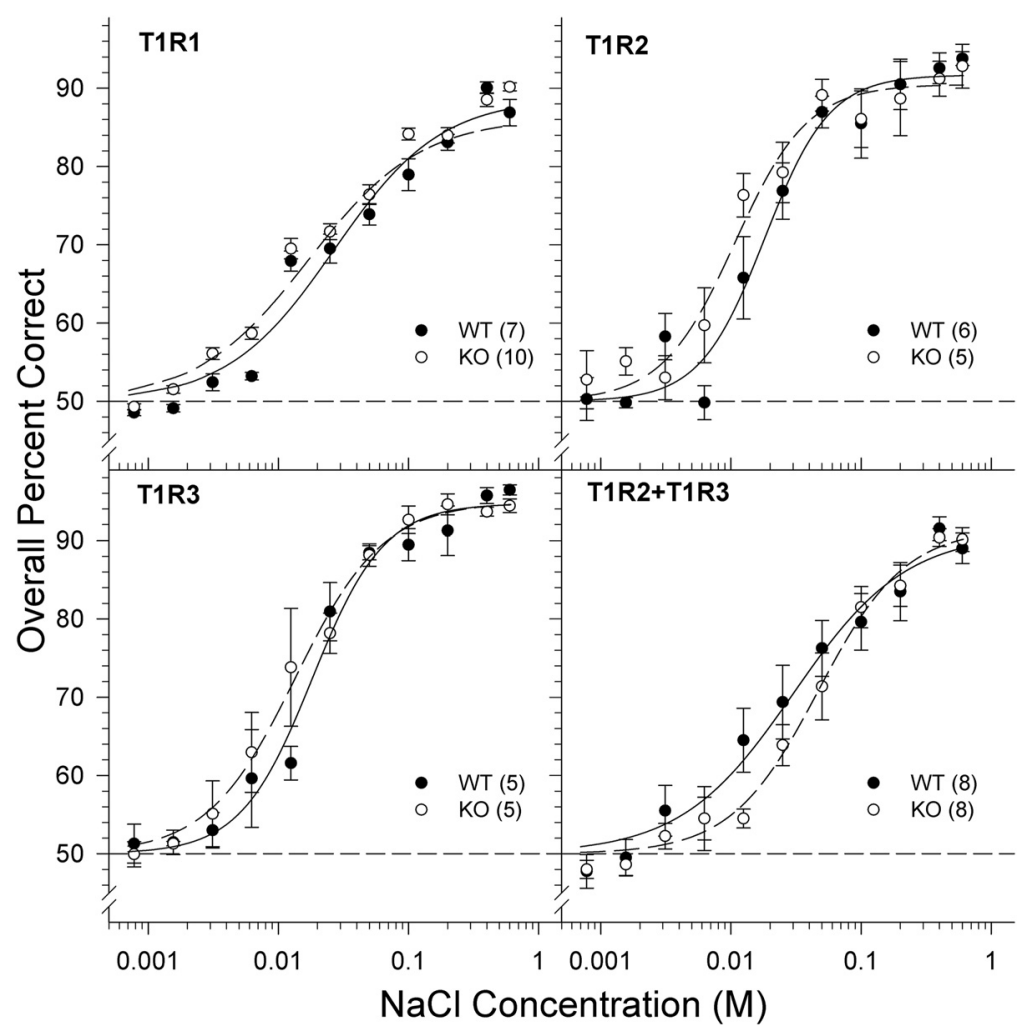

Figure 1. Data are mean $\pm \mathrm{SE}$ of the overall percent correct scores as a function of $\mathrm{NaCl}$ concentration for T1R1 (top left), T1R2 (top right), T1R3 (bottom left), and T1R2 + T1R3 (bottom right) groups. Chance performance is $50 \%$. The curves representing the psychometric functions were derived by nonlinear regression for each group (see Data analysis). Black circles and solid lines represent WT mice. White circles and dashed lines represent $K 0$ mice. The sample size of each genotype is indicated in parentheses.

omitted this stimulus from the test stimulus array given the following: (1) the increasing age of the animals; (2) the necessity to test $0.6 \mathrm{M}$ MSG prepared with $100 \mu \mathrm{M}$ amiloride and $2.5 \mathrm{~mm}$ IMP; and (3) the possibility of losing stimulus control resulting from prolonged testing with a very weak or undetectable stimulus.

An additional test was conducted in these T1R2 + T1R3 KO mice to functionally confirm the genotype of the animals. A 2-bottle sodium saccharin (Na-saccharin; Sigma) versus water preference test was performed because T1R2 + T1R3 KO mice do not prefer $10 \mathrm{~mm} \mathrm{Na}$ saccharin over water, whereas WT mice demonstrate a large preference for the sweetener (Treesukosol and Spector, 2012). Two modified $25 \mathrm{ml}$ graduated pipettes with a stainless steel drinking spout at one end and a closed stopper at the other were placed side-by-side on each home-cage with one containing $10 \mathrm{~mm} \mathrm{Na}$-saccharin and the other containing deionized, reverse-osmosis water. Intake was measured across two $24 \mathrm{~h}$ periods. Following the first $24 \mathrm{~h}$ measurement, the intake tubes were filled with newly prepared solution and the position of the tubes was switched to control for potential side-biases. A final intake measure was taken at $48 \mathrm{~h}$. One WT mouse had a clogged bottle on one day and so that animal was retested.

Data analysis. Psychometric detectability functions were generated and statistical analyses were conducted like those in Experiment 1. The Na-saccharin preference ratios were derived by dividing Na-saccharin intake by total intake. The preference ratios from WT and T1R2 + T1R3 KO mice were subjected to onesample $t$ tests to assess significant departures from indifference (preference ratio $=0.5$ ). One KO mouse and 1 WT mouse died during $\mathrm{NaCl}$ training, and $1 \mathrm{WT}$ and $1 \mathrm{KO}$ mouse died during $\mathrm{NaCl}$ testing, leaving a total of 8 mice per group for the experiment. The detection score for $0.4 \mathrm{M} \mathrm{NaCl}$ was not obtained for one T1R3 WT mouse; thus, the animal's scores for $0.6 \mathrm{M}$ and $0.2 \mathrm{M}$ were averaged for the data analysis.

\section{Experiment 3}

Subjects. The original male and female breeding pairs were homozygous null for the T1R1 gene (derived from 129 mice and backcrossed with B6 mice for at least three generations) and were provided by Dr. Charles Zuker (Columbia University). These mice were crossed with WT B6 mice (The Jackson Laboratory) to produce T1R1 heterozygous mice. These heterozygous mice were bred to produce T1R1 WT and homozygous null offspring such that the same-sex WT and T1R1 KO littermates served as pairs of subjects in the experiment ( $N=10$ /genotype; 10 male, 10 female). Not all of these subjects were retained in the experiment as a result of death or failure to meet established criteria, but the littermates were retained. Genotypes were confirmed as in Experiment 1. Four of the 
Table 3. $t$ test results comparing the psychometric curve parameters in mice that performed at $\geq 80 \%$ accuracy on the highest test concentration presented in the detection task

\begin{tabular}{|c|c|c|c|}
\hline Group & Asymptote (a) & Slope $(b)$ & $\mathrm{EC}_{50}(c)$ \\
\hline \multicolumn{4}{|l|}{$\mathrm{NaCl}$} \\
\hline T1R1 & $t_{(14)}=0.741, p=0.471$ & $t_{(14)}=1.705, p=0.110$ & $t_{(14)}=0.165, p=0.871$ \\
\hline T1R2 & $t_{(9)}=-0.993, p=0.347$ & $t_{(9)}=0.549, p=0.597$ & $t_{(9)}=-1.610, p=0.142$ \\
\hline $\mathrm{T} 1 \mathrm{R} 2+\mathrm{T} 1 \mathrm{R} 3$ & $t_{(14)}=0.978, p=0.345$ & $t_{(14)}^{(0)}=0.871, p=0.398$ & $t_{(14)}=1.324, p=0.207$ \\
\hline \multicolumn{4}{|l|}{ MSG } \\
\hline T1R1 & $t_{(15)}=0.343, p=0.736$ & $t_{(15)}=-0.343, p=0.736$ & $t_{(15)}=-0.261, p=0.798$ \\
\hline $\mathrm{T} 1 \mathrm{R} 2+\mathrm{T} 1 \mathrm{R} 3$ & $t_{(13)}=0.909, p=0.380$ & $t_{(13)}=0.740, p=0.472$ & $t_{(13)}=1.492, p=0.160$ \\
\hline \multicolumn{4}{|l|}{ L-Lysine } \\
\hline T1R1 & $t_{(14)}=0.658, p=0.521$ & $t_{(14)}=-0.066, p=0.948$ & $t_{(14)}=1.116, p=0.283$ \\
\hline
\end{tabular}

T1R1 KO and two T1R1 WT mice were found to have the 129 Tas1r3 allele and not the B6 Tas1r3 allele that encodes for the T1R3 protein. Statistical analyses were conducted comparing the responses of the mice having the 129 Tas $1 r 3$ allele with the mice having the B6 Tas1r3 allele in the WT and KO groups. No significant differences between the two KO genotypes and two WT genotypes were observed across the multiple stimulus concentration series, and, importantly, given the low sample sizes, there were no ostensible trends suggesting otherwise, with one exception noted in the results. Therefore, the data from all T1R1 KO and WT mice were collapsed for statistical analyses, except where noted. All T1R1 animals were adults at the start of the experiment with a body weight range of 21.1-32.6 g. Mice were maintained in the same conditions as Experiments 1 and 2.

Stimuli and procedure. Mice were trained in gustometers identical to those in Experiment 1 . The training and testing protocol was similar to Experiment 1 with the addition of the test stimulus L-lysine monohydrochloride (L-lysine; Sigma) and adjustments to the stimulus order as outlined in Table 1. A series of three 2-bottle preference tests was conducted with these animals pitting $100 \mu \mathrm{M}$ amiloride against $2.5 \mathrm{~mm}, 5 \mathrm{~mm}$, and $10 \mathrm{~mm}$ IMP prepared with $100 \mu \mathrm{M}$ amiloride each over a $48 \mathrm{~h}$ period with the test of each concentration separated by $3 \mathrm{~d}$.

Data analysis. Psychometric detectability functions were generated and statistical analyses were conducted as described in Experiment 1. Additional one-sample $t$ tests were conducted to examine whether the IMP preference ratios significantly differed from indifference in WT and KO mice. Two T1R1 WT mice did not reach the learning criterion established for inclusion in $\mathrm{NaCl}$ testing and therefore were eliminated from the experiment. One WT mouse died during $\mathrm{NaCl}$ training, leaving the group sizes as follows: T1R1 KO mice $(N=10)$ and T1R1 WT mice $(N=7)$. The detection score for $0.4 \mathrm{M}$ $\mathrm{NaCl}$ was not obtained for one T1R1 KO mouse; thus, the scores for $0.6 \mathrm{M}$ and $0.2 \mathrm{M}$ were averaged for the data analysis. Two WT mice did not take trials on one of the MSG + amiloride training days, and one WT mouse fell $<80 \%$ of its nondeprived body weight and therefore had its home-cage water temporarily replaced and was excluded from $2 \mathrm{~d}$ of MSG + amiloride training. In these cases, the overall percent correct scores preceding and following the missing session(s) for each subject were averaged for data presentation.

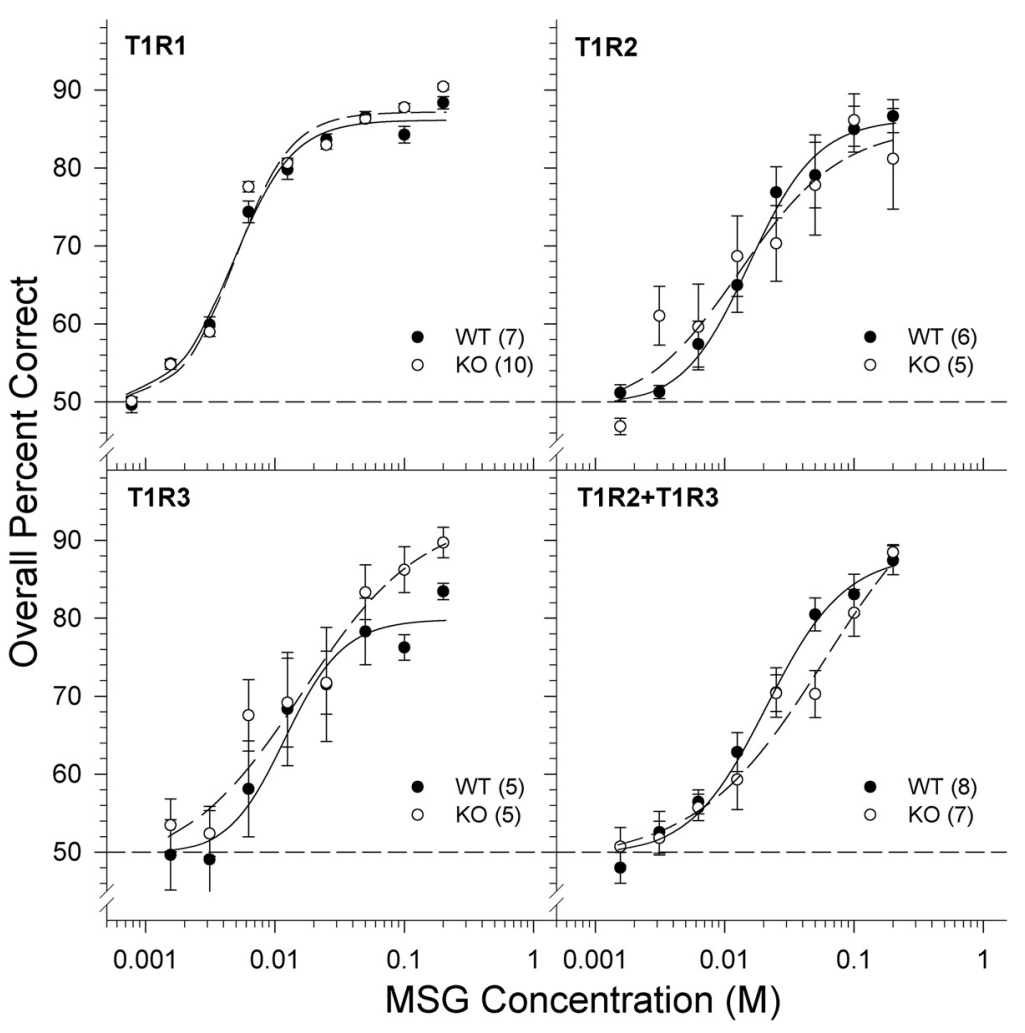

Figure 2. Data are mean $\pm S E$ of the overall percent correct scores as a function of MSG concentration for T1R1 (top left), T1R2 (top right), T1R3 (bottom left), and T1R2 + T1R3 (bottom right) groups. Chance performance is 50\%. The curves representing the psychometric functions were derived by nonlinear regression for each group (see Data analysis). Black circles and solid lines represent WT mice. White circles and dashed lines represent $K 0$ mice. The sample size of each genotype is indicated in parentheses.

\section{Results}

The results of the three experiments were combined and segregated by stimulus for a more cohesive presentation of the outcomes for comparison.

\section{$\mathrm{NaCl}$}

The two-way ANOVAs (Table 2) assessing the overall percent correct scores across $\mathrm{NaCl}$ concentrations revealed no main effect or interaction of genotype for all of the groups (T1R1, T1R2, T1R3, and T1R2 + T1R3). As expected, a main effect of concentration was revealed across groups such that performance declined as the concentration of $\mathrm{NaCl}$ was decreased (Fig. 1). The analysis of asymptote $(a)$, slope $(b)$, and $\mathrm{EC}_{50}(c)$ parameters derived from the individual animal curve fits indicated no statistically significant differences between groups (Table 3). Collec- 


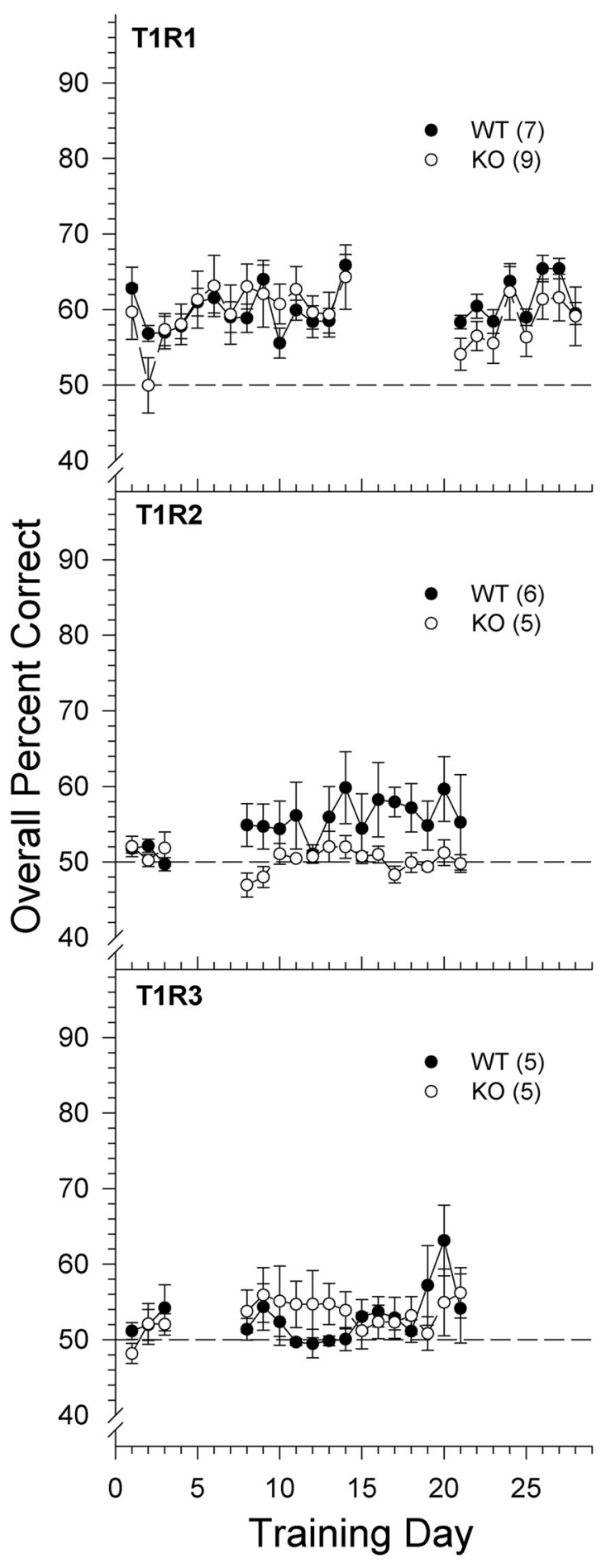

Figure 3. Data are mean $\pm S E$ of the overall percent correct scores across training days to 0.6 M MSG mixed with $100 \mu \mathrm{m}$ amiloride for T1R1 (top), T1R2 (middle), and T1R3 (bottom) groups. Chance performance is $50 \%$. Breaks in curves represent a return to side training. Black circles and solid lines represent WT mice. White circles and dashed lines represent $\mathrm{KO}$ mice. The sample size of each genotype is indicated in parentheses.

tively, these analyses demonstrate that all $\mathrm{KO}$ genotypes showed normal (i.e., comparable with their WT counterparts) sensitivity to $\mathrm{NaCl}$ as is evident by the similar detection curves between $\mathrm{KO}$ and WT mice (Fig. 1). Furthermore, the lack of difference in performance on the $\mathrm{NaCl}$ taste detection test between $\mathrm{KO}$ mice and their respective WT controls suggests that any differences in taste sensitivity to the subsequent test stimuli between genotypes can be attributed to the genetic manipulation of the respective $\mathrm{T} 1 \mathrm{R}$ proteins and not to an inability to learn or execute the tworesponse discrimination procedure.

\section{MSG}

One T1R2 + T1R3 KO mouse did not perform above chance on the final day of MSG training and therefore was not included in the following analyses. The two-way ANOVAs assessing the overall percent correct scores across MSG concentrations revealed no significant effect of genotype or genotype $\times$ concentration interactions for the T1R1, T1R3, and T1R2 + T1R3 groups (Table 2; Fig. 2). Likewise, no main effect of genotype was found in the T1R2 groups, but a genotype $\times$ concentration interaction was observed. Bonferroni-corrected $t$ tests revealed no significant differences between genotypes across concentrations, however. As expected, there was a main effect of concentration for all groups indicating that performance, and therefore stimulus detectability, decreased as concentration was lowered (Fig. 2; Table 2). The analysis of asymptote $(a)$, slope $(b)$, and $\mathrm{EC}_{50}(c)$ parameters derived from the individual animal curve fits indicated no statistically significant differences between genotypes (Table 3 ). As was the case for $\mathrm{NaCl}$, the absence of differences between the $\mathrm{KO}$ and the WT mice indicates that the gene deletion(s) had no effect on MSG detectability in this task. The lack of a functional T1R1, T1R2, or T1R3 protein, or even the combined absence of both T1R2 and T1R3, does not affect the taste sensitivity of mice to MSG. The missing T1R protein(s) may, however, affect the qualitative perception of MSG in these KO animals, a possibility that these experiments was not designed to address.

\section{MSG $+100 \mu \mathrm{M}$ amiloride}

Because the competent performance of the KO mice when MSG was the stimulus may have been driven by the sodium cation, we tested the T1R1, T1R2, and T1R3 groups with MSG dissolved in a solution containing the ENaC blocker amiloride, which is tasteless to rodents (Markison and Spector, 1995; Eylam et al., 2003). Initially, we presented $0.2 \mathrm{M}$ MSG with $100 \mu \mathrm{M}$ amiloride to the T1R2 and T1R3 groups for $2 \mathrm{~d}$, but following poor discrimination performance by the mice, we increased the MSG concentration to $0.6 \mathrm{M}$. This concentration was then made the training concentration for the T1R1 group. When the mice failed to improve performance, side-training was reinstated to serve as a reminder of the contingencies of the task for the animals. This was followed by further discrimination training. To our surprise, no marked improvement in performance was observed in the T1R2 WT and $\mathrm{KO}$ mice or T1R3 WT and KO mice across 17 discrimination training sessions or in T1R1 WT or KO mice across 22 discrimination training sessions (Fig. 3). Therefore, training was ceased to prevent loss of stimulus control. A two-way ANOVA comparing performance on the first and last training day to 0.6 M MSG with $100 \mu \mathrm{M}$ amiloride did not reveal any significant main effects or interaction of gene deletion or experience in the T1R1, T1R2, or T1R3 groups (all $p$ values $\geq 0.097$ ). A binomial distribution test was conducted on the overall percent score of each mouse on the last day of training to determine whether animals were detecting the stimulus above chance levels. One of 5 T1R3 KO and 1 of 5 T1R3 WT, 1 of 6 T1R2 WT mice and no T1R2 KO mice, and 5 of 9 T1R1 KO and 2 of 7 T1R1 WT mice were able to detect $0.6 \mathrm{M}$ MSG with $100 \mu \mathrm{M}$ amiloride above chance levels, albeit very poorly. A two-way ANOVA comparing performance of the T1R1 $\mathrm{KO}$ mice on the first and last training day as a function of the Tas1r3 allele revealed that T1R1 KO mice having the B6 Tas1r3 
allele performed better than the T1R1 KO mice having the 129 Tas1r3 allele $\left(F_{(1,7)}=\right.$ 9.106, $p=0.019)$, but there was no effect of experience (i.e., training day; $F_{(1,7)}=$ $0.031, p=0.866)$ or interaction $\left(F_{(1,7)}=\right.$ $0.367, p=0.564)$. No such significant effect of the Tas1r3 allele was observed in the T1R1 WT, but the sample size was small. The T1R1 KO mice with the B6 Tas1r3 allele still performed poorly to this relatively high MSG concentration (mean $\pm \mathrm{SE}$; overall percentage correct score on Training Day 22: B6 = $65.9 \pm$ 2.92; $129: 50.7 \pm 5.69$ ), and there were no differences between the performance of T1R1 KO mice with the B6 versus 129 Tas1r3 allele observed with any other stimulus, including MSG + amiloride + IMP. Moreover, the B6 Tas1r3 allele did not appear to confer any obvious advantage in detecting MSG + amiloride in WT mice. The slight, but significant, ability of some of the T1R1 KO and T1R1 WT mice, regardless of the present Tas1r3 allele, to detect MSG + amiloride may be attributed to their experience with the amplifying effects of IMP on the taste of L-glutamate before their exposure with L-glutamate alone; the T1R2 and T1R3 mice received the reverse stimulus testing order. This effect of experience may have facilitated the performance of the T1R1 $\mathrm{KO}$ and T1R1 WT animals in the task by sensitizing them to attend to very weak signals. Such an effect of experience was observed in a prior study (Treesukosol and Spector, 2012). Nevertheless, when the ENaC pathway is blocked by amiloride, MSG is rendered a weak stimulus or even undetectable. Because we were unable to train the T1R2 group or the T1R3 group to discriminate $0.6 \mathrm{M} \mathrm{MSG}+100 \mu \mathrm{M}$ amiloride from $100 \mu \mathrm{M}$ amiloride alone, we did not test the T1R2 + T1R3 mice with that particular stimulus and proceeded to assess sensitivity to descending concentrations of MSG prepared with both $100 \mu \mathrm{M}$ amiloride and 2.5 mM IMP.

\section{MSG $+100 \mu \mathrm{M}$ amiloride $+2.5 \mathrm{~mm}$ IMP}

One T1R3 KO mouse died during training. Four T1R2 + T1R3 $\mathrm{KO}$ mice and four T1R1 KO mice were unable to learn the 100 $\mu \mathrm{M}$ amiloride versus $0.6 \mathrm{M}$ MSG $+100 \mu \mathrm{M}$ amiloride $+2.5 \mathrm{~mm}$ IMP discrimination task, suggesting that detection of the compound stimulus was difficult for the KO mice lacking T1R1 or T1R3. These animals were reintroduced to the stimulus control maintenance phase $(0.6 \mathrm{M} \mathrm{NaCl}$ vs water discrimination $)$ throughout the remainder of training and testing for this particular stimulus and were therefore not included in the following analyses. The two-way ANOVA conducted on overall percent correct scores across MSG concentrations in T1R2 mice revealed a main effect of concentration and genotype but no genotype $\times$ concentration interaction. However, further $t$ tests performed on overall percent correct scores per concentration revealed no significant differences in performance between KO and WT mice (all Bonferroni-adjusted $p$ values $\geq 0.477$ ). Furthermore, both $\mathrm{WT}$ and $\mathrm{KO}$ mice performed with high accuracy at each concentration presented (Fig. 4). These data show that T1R2 KO mice are relatively unimpaired in their ability to detect MSG in the presence of IMP. As will be shown, this was due to the clear detectability of the $2.5 \mathrm{~mm}$ IMP in both T1R2 KO and all WT groups alike.

The two-way ANOVAs comparing the overall percent correct scores of T1R1, T1R3, and T1R2 + T1R3 KO mice with their respective WT controls across MSG concentrations presented in solution with $100 \mu \mathrm{M}$ amiloride and $2.5 \mathrm{~mm}$ IMP revealed a main effect of concentration and genotype as well as a genotype $\times$ concentration interaction (Table 2; Fig. 4). Because of the interaction, one-way ANOVAs were conducted on the overall percent correct scores to determine concentration-dependent responsiveness within each genotype. A main effect of concentration was observed within the T1R1 KO mice $\left(F_{(8,40)}=9.581, p<\right.$ $0.001)$, T1R3 KO mice $\left(F_{(8,16)}=4.289, p=0.006\right)$, and T1R2 + T1R3 KO mice $\left(F_{(8,24)}=5.728, p<0.001\right)$ such that performance declined as stimulus concentration was lowered. In contrast, no main effect of concentration was observed in the WT counterparts ( $p$ values $\geq 0.067$ ); WT mice performed with high accuracy across all concentrations, as observed in the T1R2 group. Bonferroni-corrected $t$ tests revealed that T1R1 WT, T1R3 WT, and T1R2 + T1R3 WT mice were able to discriminate the following concentrations significantly better than their $\mathrm{KO}$ counterparts: T1R1 (0.003-0.2 $\mathrm{M}$ and $0.6 \mathrm{M}$, all $p \leq 0.045)$; T1R3 $(0.006 \mathrm{M}$, $0.0125 \mathrm{M}, 0.05-0.6 \mathrm{M}, p \leq 0.018)$; and T1R2 + T1R3 KO (0.003-0.4 $\mathrm{M} ; p \leq 0.009)$. Unlike the T1R2 KO mice, only at higher concentrations of the test stimulus were the T1R1 KO mice $\left(0.6 \mathrm{M}: t_{(5)}=\right.$ 


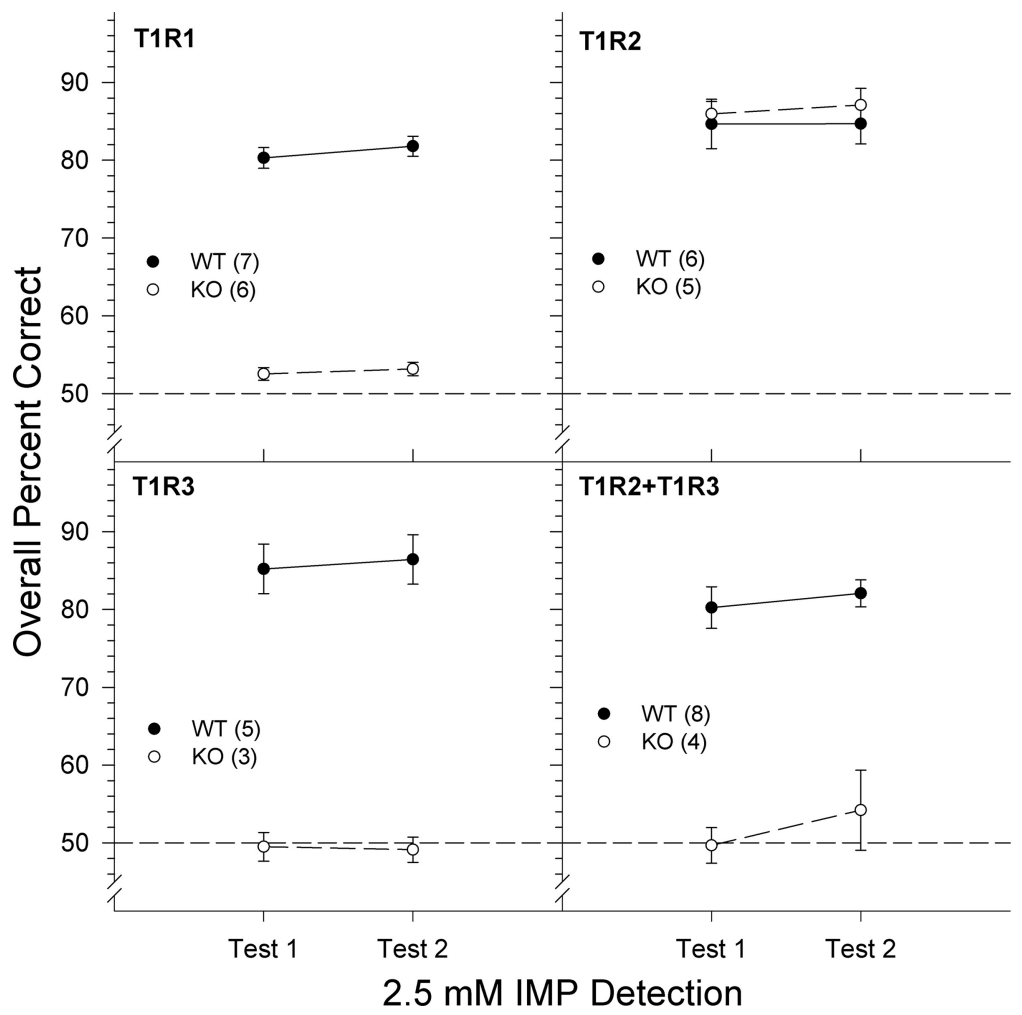

Figure 5. Data are mean \pm SE of the overall percent correct scores for T1R1 (top left), T1R2 (top right), T1R3 (bottom left), and $\mathrm{T} 1 \mathrm{R} 2+\mathrm{T} 1 \mathrm{R} 3$ (bottom right) groups on the 2 test days of a $2.5 \mathrm{~mm} \mathrm{IMP}+100 \mu \mathrm{M}$ amiloride versus $100 \mu \mathrm{m}$ amiloride discrimination task. Chance performance is 50\%. Black circles and solid lines represent WT mice. White circles and dashed lines represent KO mice. The sample size of each genotype is indicated in parentheses.

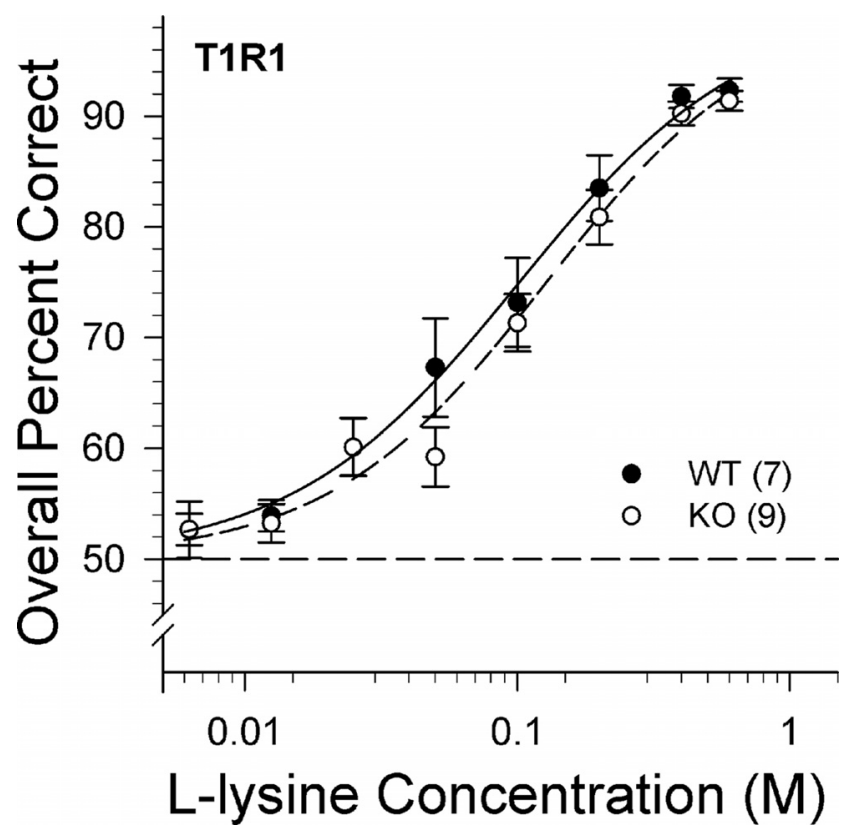

Figure 6. Data are mean \pm SE of the overall percent correct scores as a function of $L$-lysine concentration for T1R1 WT (black circles and solid lines) and KO (white circles and dashed lines) mice. Chance performance is $50 \%$. The curves representing the psychometric functions were derived by nonlinear regression for each group (see Data analysis). The sample size of each genotype is indicated in parentheses.

$7.969, p=0.002 ; 0.4 \mathrm{M}: t_{(5)}=4.301, p=0.036 ; 0.2 \mathrm{M}: t_{(5)}=7.511$; $p=0.003)$ and the T1R2 $+\mathrm{T} 1 \mathrm{R} 3 \mathrm{KO}$ mice $\left(0.6 \mathrm{M}: t_{(3)}=5.952\right.$, $\left.p=0.041 ; 0.4 \mathrm{M}: t_{(3)}=13.671, p=0.004\right)$ able to perform above chance as determined by a one-sample Bonferroni-corrected $t$ test (one-tailed), albeit performance was compromised (Fig. 4). The test of the above chance performance of the T1R3 $\mathrm{KO}$ mice at $0.6 \mathrm{M}\left(t_{(2)}=5.476, p=0.032\right)$ failed to survive Bonferroni adjustment $(p=0.142)$. Thus, the T1R1, T1R3, and T1R2 + T1R3 KO mice were significantly impaired in their ability to detect MSG (mixed with amiloride) even in the presence of the L-glutamate signal-potentiating IMP confirming the importance of the T1R1 + T1R3 heterodimer in L-glutamate taste sensitivity. Yet, at the same time, these particular KO groups were able to display partial competence at detecting the higher MSG (mixed with amiloride) concentrations when mixed with IMP, suggesting that the presence of both subunits of the heterodimer are not necessary for some degree of taste detection of this stimulus to be behaviorally displayed.

\section{$2.5 \mathrm{~mm}$ IMP $+100 \mu \mathrm{M}$ amiloride}

Given the lack of concentrationdependent responding in all of the WT groups and in the T1R2 KO mice to MSG $+100 \mu \mathrm{M}$ amiloride $+2.5 \mathrm{~mm}$ IMP, we hypothesized that these mice were able to use the taste cue from the IMP to perform the task, whereas the T1R1, T1R3, and T1R2 + T1R3 KO mice were unable to do so. We therefore conducted a $2.5 \mathrm{~mm}$ IMP $+100 \mu \mathrm{M}$ amiloride versus $100 \mu \mathrm{M}$ amiloride discrimination test across $2 \mathrm{~d}$. Two-way ANOVAs revealed a significant main effect of genotype for the T1R1 group $\left(F_{(1,11)}=66.033, p<0.001\right)$, the T1R3 group $\left(F_{(1,7)}=98.380, p<0.001\right)$, and the T1R2 + T1R3 group $\left(F_{(1,10)}=141.919, p<0.001\right)$. There was no main effect of genotype in the T1R2 group and no main effects or interactions involving test day across all groups (all $p>0.376$ ). Mice from all of the WT groups and the T1R2 KO mice were able to discriminate the IMP (mixed with amiloride) stimulus from amiloride with high accuracy (all $p$ values $<0.001$ ), whereas the T1R1 KO, T1R3 KO, and T1R2 + T1R3 KO mice failed to respond above chance as determined by a one-sample $t$ test (all $p$ values $\geq 0.263$, one-tailed; Fig. 5).

\section{L-Lysine}

The T1R1 KO mice did not demonstrate any deficits in their ability to discriminate L-lysine from water. No main effect or interaction of genotype was identified, but a main effect of concentration was found indicating that performance of the T1R1 $\mathrm{KO}$ and WT mice significantly decreased as the concentration was lowered (Table 2; Fig. 6). The analysis of asymptote (a), slope $(b)$, and $\mathrm{EC}_{50}(c)$ parameters derived from the individual animal curve fits indicated no statistically significant differences between the KO and WT mice (Table 3). The similar psychometric functions between T1R1 KO and T1R1 WT mice indicate that the gene deletion caused no deficits in the detection of L-lysine and demonstrate that T1R1 + T1R3 is not necessary for maintaining normal sensitivity to all L-amino acids. Although sensitivity was unaffected, this experiment was not designed to assess the possible impact of the T1R manipulation on the qualitative nature of the stimulus. 


\section{Water control test}

At the conclusion of the detection experiments, each stimulus reservoir was filled with water; half was assigned as "water" and the other half was assigned as "tastant" to confirm that the animals were, indeed, using chemical cues to perform the previous discriminations. Two T1R2 WT mice, three T1R2 KO mice, one T1R3 KO mouse, one T1R2 + T1R3 WT mouse, and one T1R2 + T1R3 KO mouse died during the prior stimulus control phase; thus, no data could be collected for the water control test. The T1R2, T1R3, and T1R2 + T1R3 groups had two "water control test" days, for which the average performance was taken, and the T1R1 group was given 1 d. One T1R2 + T1R3 WT mouse performed above chance on the water control test, albeit poorly, but demonstrated chance performance at lower concentrations of the test stimuli when expected. All other mice performed at chance levels as determined by a one-tailed binomial distribution test. These data demonstrate that performance on the previous tests was based on orosensory and not extraneous cues (Fig. 7).

\section{Two-bottle $10 \mathrm{~mm}$ Na-saccharin preference test}

T1R2 + T1R3 WT mice showed a nearly complete preference for $10 \mathrm{~mm}$ Na-saccharin over water $\left(t_{(6)}=19.384, p<0.001\right)$, whereas the T1R2 + T1R3 KO mice showed no such preference $\left(t_{(6)}=-1.621, p=0.156\right.$; Fig. 8$)$ as determined by a one-sample $t$ test.

\section{Two-bottle IMP preference tests}

A two-way ANOVA measuring the preference of T1R1 WT and $\mathrm{KO}$ mice for 2.5, 5, and $10 \mathrm{mM}$ IMP (all mixed with $100 \mu \mathrm{M}$ amiloride) versus $100 \mu \mathrm{M}$ amiloride found no main effect of genotype $\left(F_{(1,13)}=0.130, p=0.725\right)$ or concentration $\left(F_{(2,26)}=\right.$ $0.292, p=0.749)$ and no concentration $\times$ genotype interaction $\left(F_{(2,26)}=0.901, p=0.418\right)$. As evident in Figure 9, neither T1R1 WT nor T1R1 KO mice showed a preference for any of the IMP concentrations (with $100 \mu \mathrm{M}$ amiloride) presented, as determined by a series of one-sample $t$ tests (all Bonferroni-corrected $p$ values $>0.05)$. Although IMP is clearly detectable to the T1R1 WT mice (Fig. 5), the lack of a preference for IMP across the tested concentrations highlights the need to interpret the outcome of intake tests with caution regarding the assessment of taste sensitivity.

\section{Discussion}

Our findings challenge current views of "umami" taste perception by psychophysically demonstrating that WT and KO mice, regardless of the missing T1R protein(s), have difficulty reliably detecting a relatively high concentration of MSG when the contribution of sodium is minimized by amiloride, and animals are forced to make immediate decisions on the presence or absence of a taste stimulus after a few licks. The latter methodological features increase the confidence that the behavior was guided by orosensory cues and suggests that, perceptually speaking, L-glutamate alone is a weak taste stimulus, at best, to mice.

Whereas WT and T1R2 KO mice were able to detect all presented concentrations of MSG + amiloride (i.e., L-glutamate) when IMP was added, because they could detect the 5'-

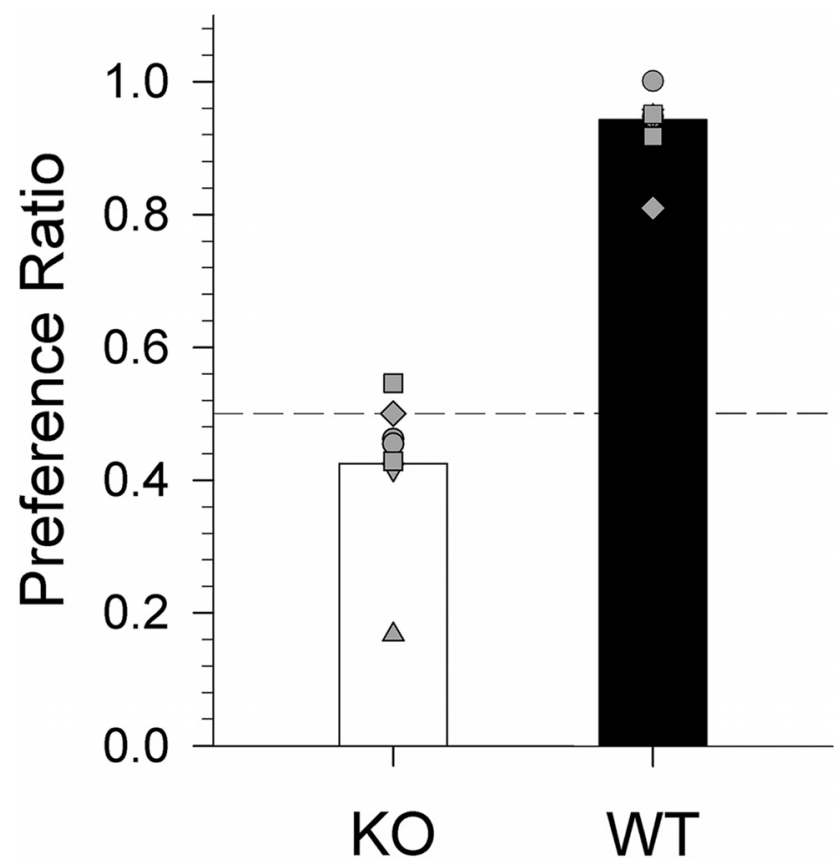

Figure 8. Data are mean \pm SE. Na-saccharin preference ratio for T1R2 + T1R3 WT (closed bar) and T1R2 + T1R3 K0 (open bar) mice in a $48 \mathrm{~h}$ 2-bottle preference test (10 mM Nasaccharin vs water). Gray shapes represent individual mouse scores.

ribonucleotide alone, mice lacking T1R1 or T1R3 were only able to detect the higher L-glutamate concentrations of the compound stimulus. The severe difficulty or inability of the T1R1, T1R3, and $\mathrm{T} 1 \mathrm{R} 2+3 \mathrm{KO}$ mice to detect IMP or MSG (both with amiloride) suggests that the detection of these stimuli when combined, at least at relatively high MSG concentrations, by some of these KO mice may be due to the documented synergistic effect of IMP on the L-glutamate taste signal (Damak et al., 2003; e.g., Zhao et al., 2003; Tokita et al., 2012; Kusuhara et al., 2013). Given that the behavioral profile of the T1R2 KO mice in this task resembled that of the WT mice and not that of the other KO mice, the premise that the putative sweet taste of MSG in rodents arises from the T1R2 + T1R3 receptor is weakened.

We also tested whether sensitivity deficits observed in the T1R1 KO mice to MSG + amiloride + IMP would be evident with a different L-amino acid, L-lysine. Deleting the T1R1 subunit had no effect on lysine detection. L-Lysine in particular has been 


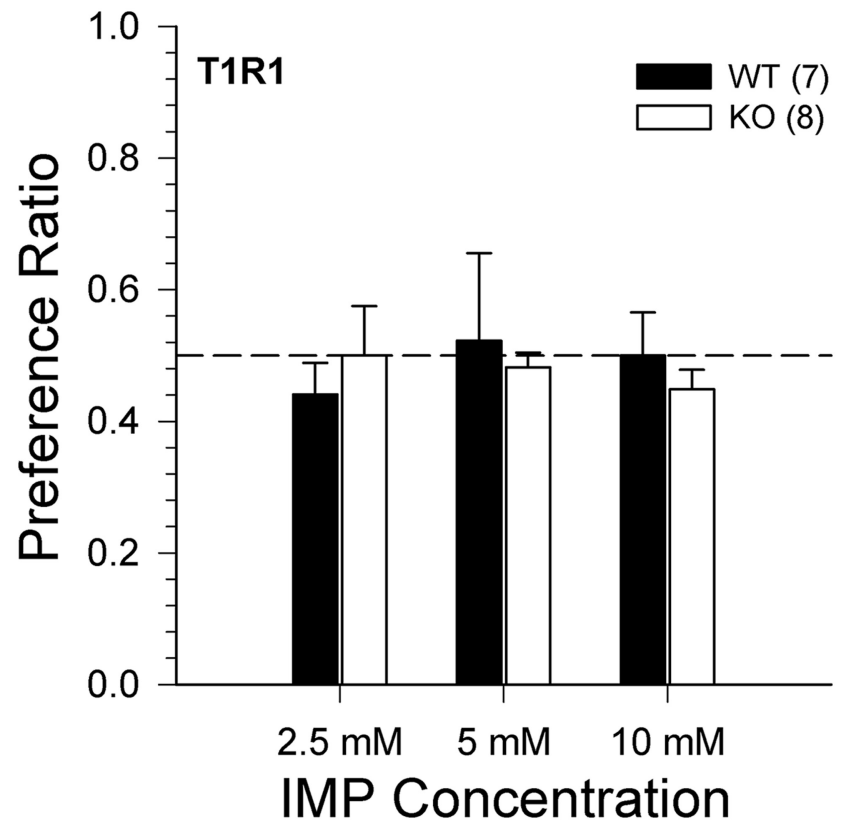

Figure 9. Data are mean \pm SE. IMP preference ratio for T1R1 WT (closed bars) and T1R1 K0 (open bars) mice in three $48 \mathrm{~h}$ 2-bottle preference test (IMP + amiloride vs amiloride) as a function of IMP concentration. The sample size of each genotype is indicated in parentheses.

described as having a bitter component to humans (Schiffman and Sennewald, 1981; Kawai et al., 2012) and is avoided by mice (e.g., Ninomiya et al., 1994), suggesting that L-lysine may be binding with T2Rs (i.e., taste receptors for bitter ligands), in addition to binding to the T1R1 + T1R3 heterodimer (Nelson et al., 2001, 2002). In support, orally applied L-lysine activates quininebest taste neurons in the parabrachial nucleus of B6 mice (Tokita et al., 2012). Apparently, the T1R1 + T1R3 heterodimer is not necessary for the maintenance of normal taste sensitivity to all L-amino acids and accordingly should not be considered the absolute L-amino acid receptor in mammals. Amino acid taste perception is clearly qualitatively complex (e.g., Schiffman and Sennewald, 1981; Pritchard and Scott, 1982; Kawai et al., 2012).

In addition to our findings, others have shown that amiloride has large effects on responses to MSG in rodents (Formaker et al., 2004; Glendinning et al., 2005; Murata et al., 2009), indicating that the sodium cation contributes significantly to MSG taste. Thus, distinguishing the effects of the sodium ion from the effects of L-glutamate is interpretively challenging. Indeed, neuronal responses to orally applied MSG track those to sodium salts in the nucleus of the solitary tract of both WT and T1R3 KO mice (Lemon and Margolskee, 2009; but see Stratford and Finger, 2011). Even when amiloride (or monopotassium glutamate [MPG]) is used, the cation could still be transduced through the nonselective ENaC-independent pathway(s). However, at the concentrations used in our study, it is unlikely that much of a detectable sodium signal remained when animals sampled MSG + amiloride, as the data attest (compare Eylam and Spector 2002, 2003; Treesukosol et al., 2007). Therefore, outcomes from studies using MSG without amiloride in rodents should not be expected to be consistent with the findings reported here regarding L-glutamate detectability.

There are, however, rodent studies in which amiloride had little effect on behavioral responsiveness to MSG. For example, using a brief access lick test, Delay et al. (2007) reported success- ful conditioning of taste aversions in rats to $0.1 \mathrm{M}$ MSG mixed with $30 \mu \mathrm{M}$ amiloride that cross-generalized with aversions conditioned to glycine, L-serine, and L-arginine (all mixed with amiloride). Nakashima et al. (2012) reported that aversions conditioned to $0.03 \mathrm{M}$ MSG (without amiloride) in mice generalized to test concentrations as low as $0.7 \mu \mathrm{M}$ MSG with or without 10 $\mu \mathrm{M}$ amiloride. Delay et al. (2006), using a shock avoidance task, found that amiloride did not shift the detection threshold for MSG in either WT or T1R3 KO mice. It should be noted, however, that, for whatever reason, this latter task is not always sensitive to the effects of amiloride, even on $\mathrm{NaCl}$ detectability (Ruiz et al., 2006). In these MSG studies, there was no test of the effectiveness of amiloride on $\mathrm{NaCl}$ responsiveness, which would have been useful given that others have shown that MSG has a significant sodium taste component that is attenuated by amiloride in rodents, as noted above. We saw no need to test the effect of amiloride on $\mathrm{NaCl}$ detectability because it had an uncontestable effect on responsiveness to MSG, and we have shown the effectiveness of our amiloride protocol to disrupt performance to sodium salts in studies using a psychophysical task similar to that used here (e.g., Eylam and Spector, 2002, 2003; Treesukosol et al., 2007).

The disparity observed between our findings and those of Delay et al. (2006) using T1R3 KO mice may stem from differences in the methodological features of the experiments, such as the method of punishment. Delay et al. (2006) used positive punishment in the form of an electrical shock to the tongue. Perhaps the electric current applied to the lingual surface somehow altered taste cell function. Alternatively, another possibility for differences between the studies may be the genetic manipulations used for generating the T1R3 $\mathrm{KO}$ mice. In our mice, a neocassette replaced the exons encoding the $\mathrm{N}$ terminus of the extracellular domain (exons 1-5), thus deleting the entire extracellular binding domain of the T1R3 subunit in 129 mice. These mice were then backcrossed at least three generations with B6 mice. Delay et al. (2006) used B6 mice in which the entire T1R3 coding region was removed. This does not easily explain, however, why amiloride did not alter MSG detectability in WT mice by Delay et al. (2006). The disparity may be related to the relative purity of the genetic background in the two studies, but, as assessed psychophysically, amiloride has been shown to effectively interfere with sodium taste function in both B6 and 129 mice (e.g., Eylam and Spector, 2005).

Although it is true that Zhao et al. (2003) found that WT mice licked 0.2 M MSG + amiloride more than T1R1 KO and T1R3 KO mice in a brief-access taste test, the magnitude of the response was low and represented only a fraction of the dynamic range of licking possible in the task. Indeed, the licking response of the WT mice to $0.2 \mathrm{M}$ MSG + amiloride was similar to that seen with mice lacking one of the two "sweet" taste receptor subunits (T1R2 KO, and T1R3 KO mice) when presented with $1.0 \mathrm{M}$ sucrose in the same task. These data suggest, as observed here, that the L-glutamate taste signal is weak at best when IMP is not present, at least in certain behavioral tasks.

The detectability of L-glutamate alone is an issue because, in contrast to T1R1 + T1R3, the L-glutamate signal from mGluRs is not thought to be potentiated by the presence of IMP (Ninomiya et al., 1991, 1992; Sako et al., 2000; Damak et al., 2003; Inoue et al., 2004; Kitagawa et al., 2007; Yasuo et al., 2008; Kusuhara et al., 2013). Thus, MSG + amiloride being weakly detectable, at best, weakens the argument that mGluRs are contributing to normal taste perception of this umami stimulus, at least as measured by our psychophysical task. 
Nevertheless, others have reported taste nerve responses stimulated by MSG + amiloride or MPG in T1R1 or T1R3 KO mice and that mGluR1 and mGluR4 antagonists decrease the amplitude of such responses (Yasumatsu et al., 2012; Kusuhara et al., 2013), suggesting that the brain is receiving L-glutamateevoked signals arising from taste mGluRs. Antagonists of mGluRs have also been shown to change behavioral responsiveness to MPG or MSG + amiloride (Nakashima et al., 2012; Kusuhara et al., 2013). However, it is possible that the antagonists themselves have a taste, which complicates interpretation of these behavioral outcomes. Amiloride has been effective in studies of rodent salt taste responses precisely because it has been validated to have no discernible taste itself (Markison and Spector, 1995; Eylam et al, 2003). In any event, the fact that some taste nerve fibers in T1R3 KO and WT mice respond to MPG in a fashion not potentiated by the addition of IMP supports the notion that a T1R1 + T1R3-independent signal, perhaps from taste mGluRs, is reaching the brain (Tokita et al., 2012). This does not have to mean, however, that those signals are behaviorally relevant.

In conclusion, it is clear that the perceptual detection of L-glutamate in mice is dependent, in part, on the T1R1 + T1R3 heterodimer as well as the presence of IMP, at least in our psychophysical task. It is equally clear, however, that some degree of taste detectability to this stimulus mixture can be maintained in the absence of one of the T1R1 + T1R3 subunits, supporting the possibility that either a T1R1 or T1R3 homodimer or an unidentified protein, perhaps in conjunction with T1R1 or T1R3, can serve as a low-affinity taste receptor for L-glutamate, but only in the presence of IMP. The putative IMP binding site is suggested to be near the opening of the Venus flytrap domain of the T1R1 subunit (Zhang et al., 2008; Mouritsen and Khandelia, 2012), but the taste responsiveness of some of our T1R1 KO mice to the higher concentrations of MSG (mixed with amiloride and IMP) used here, suggests that this $5^{\prime}$-ribonucleotide is capable of binding with another site. The generation of T1R1 + T1R3 double KO mice would allow for a test of the necessity of the presence of at least one subunit from the T1R1 + T1R3 heterodimer in supporting the partial behavioral competence observed in this task. Regardless of the mechanism(s) underlying the elevated performance seen toward the higher concentrations of MSG (mixed with amiloride and IMP) in mice lacking T1R1 or T1R3, the relative difficulty of all mice, $\mathrm{KO}$ and WT alike, to proficiently detect MSG + amiloride in the absence of IMP, suggests that mGluR-mediated peripheral signals are not likely being channeled into central neural circuits contributing to conscious taste perception but, rather, might be influencing other processes associated with feeding (see, Spector and Glendinning, 2009).

\section{References}

Chaudhari N, Yang H, Lamp C, Delay E, Cartford C, Than T, Roper S (1996) The taste of monosodium glutamate: membrane receptors in taste buds. J Neurosci 16:3817-3826. Medline

Chaudhari N, Landin AM, Roper SD (2000) A metabotropic glutamate receptor variant functions as a taste receptor. Nat Neurosci 3:113-119. CrossRef Medline

Damak S, Rong M, Yasumatsu K, Kokrashvili Z, Varadarajan V, Zou S, Jiang P, Ninomiya Y, Margolskee RF (2003) Detection of sweet and umami taste in the absence of taste receptor T1r3. Science 301:850-853. CrossRef Medline

Delay ER, Hernandez NP, Bromley K, Margolskee RF (2006) Sucrose and monosodium glutamate taste thresholds and discrimination ability of T1R3 knockout mice. Chem Senses 31:351-357. CrossRef Medline

Delay ER, Mitzelfelt JD, Westburg AM, Gross N, Duran BL, Eschle BK (2007)
Comparison of L-monosodium glutamate and L-amino acid taste in rats. Neuroscience 148:266-278. CrossRef Medline

Eylam S, Spector AC (2002) The effect of amiloride on operantly conditioned performance in an $\mathrm{NaCl}$ taste detection task and $\mathrm{NaCl}$ preference in C57BL/6J mice. Behav Neurosci 116:149-159. CrossRef Medline

Eylam S, Spector AC (2003) Oral amiloride treatment decreases taste sensitivity to sodium salts in C57BL/6 J and DBA/2J mice. Chem Senses 28:447458. CrossRef Medline

Eylam S, Spector AC (2005) Taste discrimination between $\mathrm{NaCl}$ and $\mathrm{KCl}$ is disrupted by amiloride in inbred mice with amiloride-insensitive chorda tympani nerves. Am J Physiol Regul Integr Comp Physiol 288:R1361R1368. CrossRef Medline

Eylam S, Tracy T, Garcea M, Spector AC (2003) Amiloride is an ineffective conditioned stimulus in taste aversion learning in C57BL/6J and DBA/2J mice. Chem Senses 28:681-689. CrossRef Medline

Formaker BK, Stapleton JR, Roper SD, Frank ME (2004) Responses of the rat chorda tympani nerve to glutamate-sucrose mixtures. Chem Senses 29:473-482. CrossRef Medline

Glendinning JI, Bloom LD, Onishi M, Zheng KH, Damak S, Margolskee RF, Spector AC (2005) Contribution of alpha-gustducin to tasteguided licking responses of mice. Chem Senses 30:299-316. CrossRef Medline

Heyer BR, Taylor-Burds CC, Tran LH, Delay ER (2003) Monosodium glutamate and sweet taste: generalization of conditioned taste aversion between glutamate and sweet stimuli in rats. Chem Senses 28:631-641. CrossRef Medline

Inoue M, Beauchamp GK, Bachmanov AA (2004) Gustatory neural responses to umami taste stimuli in C57BL/6ByJ and 129P3/J mice. Chem Senses 29:789-795. CrossRef Medline

Kawai M, Sekine-Hayakawa Y, Okiyama A, Ninomiya Y (2012) Gustatory sensation of l-and d-amino acids in humans. Amino Acids 43:2349-2358. CrossRef Medline

Kitagawa J, Takahashi Y, Matsumoto S, Shingai T (2007) Response properties of the pharyngeal branch of the glossopharyngeal nerve for umami taste in mice and rats. Neurosci Lett 417:42-45. CrossRef Medline

Kusuhara Y, Yoshida R, Ohkuri T, Yasumatsu K, Voigt A, Hübner S, Maeda K, Boehm U, Meyerhof W, Ninomiya Y (2013) Taste responses in mice lacking taste receptor subunit T1R1. J Physiol 591:1967-1985. CrossRef Medline

Lemon CH, Margolskee RF (2009) Contribution of the T1r3 taste receptor to the response properties of central gustatory neurons. J Neurophysiol 101:2459-2471. CrossRef Medline

Li X, Staszewski L, Xu H, Durick K, Zoller M, Adler E (2002) Human receptors for sweet and umami taste. Proc Natl Acad Sci U S A 99:4692-4696. CrossRef Medline

Markison S, Spector AC (1995) Amiloride is an ineffective conditioned stimulus in taste aversion learning. Chem Senses 20:559-563. CrossRef Medline

Mouritsen OG, Khandelia H (2012) Molecular mechanism of the allosteric enhancement of the umami taste sensation. FEBS J 279:3112-3120. CrossRef Medline

Murata Y, Beauchamp GK, Bachmanov AA (2009) Taste perception of monosodium glutamate and inosine monophosphate by 129P3/J and C57BL/6ByJ mice. Physiol Behav 98:481-488. CrossRef Medline

Nakashima K, Eddy MC, Katsukawa H, Delay ER, Ninomiya Y (2012) Behavioral responses to glutamate receptor agonists and antagonists implicate the involvement of brain-expressed mGluR4 and mGluR1 in taste transduction for umami in mice. Physiol Behav 105:709-719. CrossRef Medline

Nelson G, Hoon MA, Chandrashekar J, Zhang Y, Ryba NJ, Zuker CS (2001) Mammalian sweet taste receptors. Cell 106:381-390. CrossRef Medline

Nelson G, Chandrashekar J, Hoon MA, Feng L, Zhao G, Ryba NJ, Zuker CS (2002) An amino-acid taste receptor. Nature 416:199-202. CrossRef Medline

Ninomiya Y, Funakoshi M (1989) Behavioural discrimination between glutamate and the four basic taste substances in mice. Comp Biochem Physiol A Comp Physiol 92:365-370. CrossRef Medline

Ninomiya Y, Tanimukai T, Yoshida S, Funakoshi M (1991) Gustatory neural responses in preweanling mice. Physiol Behav 49:913-918. CrossRef Medline 
Ninomiya Y, Kurenuma S, Nomura T, Uebayashi H, Kawamura H (1992) Taste synergism between monosodium glutamate and 5'-ribonucleotide in mice. Comp Biochem Physiol A Comp Physiol 101:97-102. CrossRef Medline

Ninomiya Y, Kajiura H, Ishibashi T, Imai Y (1994) Different responsiveness of the chorda tympani and glossopharyngeal nerves to L-lysine in mice. Chem Senses 19:617-626. CrossRef Medline

Pritchard TC, Scott TR (1982) Amino acids as taste stimuli: II. Quality coding. Brain Res 253:93-104. CrossRef Medline

Ruiz C, Gutknecht S, Delay E, Kinnamon S (2006) Detection of $\mathrm{NaCl}$ and $\mathrm{KCl}$ in TRPV1 knockout mice. Chem Senses 31:813-820. CrossRef Medline

Sako N, Harada S, Yamamoto T (2000) Gustatory information of umami substances in three major taste nerves. Physiol Behav 71:193-198. CrossRef Medline

San Gabriel A, Maekawa T, Uneyama H, Torii K (2009) Metabotropic glutamate receptor type 1 in taste tissue. Am J Clin Nutr 90:743S-746S. CrossRef Medline

Schiffman SS, Sennewald K, Gagnon J (1981) Comparison of taste qualities and thresholds of D- and L-amino acids. Physiol Behav 27:51-59. CrossRef Medline

Spector AC, Glendinning JI (2009) Linking peripheral taste processes to behavior. Curr Opin Neurobiol 19:370-377. CrossRef Medline

Stratford JM, Finger TE (2011) Central representation of postingestive chemosensory cues in mice that lack the ability to taste. J Neurosci 31:91019110. CrossRef Medline

Tokita K, Yamamoto T, Boughter JD Jr (2012) Gustatory neural responses to umami stimuli in the parabrachial nucleus of C57BL/6J mice. J Neurophysiol 107:1545-1555. CrossRef Medline

Treesukosol Y, Spector AC (2012) Orosensory detection of sucrose, maltose, and glucose is severely impaired in mice lacking T1R2 or T1R3, but Polycose sensitivity remains relatively normal. Am J Physiol Regul Integr Comp Physiol 303:R218-R235. CrossRef Medline

Treesukosol Y, Lyall V, Heck GL, DeSimone JA, Spector AC (2007) A psychophysical and electrophysiological analysis of salt taste in Trpv1 null mice. Am J Physiol Regul Integr Comp Physiol 292:R1799-R1809. CrossRef Medline

Xu H, Staszewski L, Tang H, Adler E, Zoller M, Li X (2004) Different functional roles of T1R subunits in the heteromeric taste receptors. Proc Natl Acad Sci U S A 101:14258-14263. CrossRef Medline

Yasumatsu K, Ogiwara Y, Takai S, Yoshida R, Iwatsuki K, Torii K, Margolskee RF, Ninomiya Y (2012) Umami taste in mice uses multiple receptors and transduction pathways. J Physiol 590:1155-1170. CrossRef Medline

Yasuo T, Kusuhara Y, Yasumatsu K, Ninomiya Y (2008) Multiple receptor systems for glutamate detection in the taste organ. Biol Pharm Bull 31: 1833-1837. CrossRef Medline

Zhang F, Klebansky B, Fine RM, Xu H, Pronin A, Liu H, Tachdjian C, Li X (2008) Molecular mechanism for the umami taste synergism. Proc Natl Acad Sci U S A 105:20930-20934. CrossRef Medline

Zhao GQ, Zhang Y, Hoon MA, Chandrashekar J, Erlenbach I, Ryba NJ, Zuker CS (2003) The receptors for mammalian sweet and umami taste. Cell 115:255-266. CrossRef Medline 